\title{
NLRB ELECTIONS: UNCERTAINTY AND CERTAINTY
}

\section{Bernard Samofit $\dagger$}

Statistics continue to show an increase in inconclusive NLRB elections, ${ }^{1}$ an increase in the number of objections filed by employers, ${ }^{2}$ and an increase in the number of public reports on objections and determinative challenges. ${ }^{3}$ Whether one considers the figures alarming, interesting, or expected, they raise questions about the usefulness of elections for settling representation issues. Both the public and the labor-management community prefer elections as the means for deciding whether or not workers wish union representation. Indeed, the recent celebration of the twenty-five-millionth voter was shared by influential public and private leaders. Even the critics of the NLRB who condemn the Board's reliance upon authorization cards to establish majority representation extol the election process. In view of this apparent support, increased union and management dissatisfaction with elections certainly warrants concern.

The utility of elections lies in final, definitive and unchallenged results; elections become useless when the results are challenged, uncertain, or rejected. Elections are intended to establish and stabilize representation, not to leave it unsettled and in dispute.

This article focuses upon the functional aspect of NLRB elections, namely, deciding questions of representation. My major thesis is that definitive election results are needed to satisfy representational requirements. I seek to direct attention to the consequences of inconclusive elections, and to present a viewpoint from which to look at the increasing number of objections. There is here no exposition or analysis of decisions, no discussion of free speech, and no criticism of campaign tactics or electioneering. Primarily, I view the increasing number of inconclusive elections from the perspective of a participating administrator. For "data" I rely upon my quarter-century with the NLRB. During this period I have been involved directly in investigating, researching, and reporting some 550 cases of objections and challenges.

$\uparrow$ Regional Director, NLRB Region Four (Philadelphia). The discussion, analysis, and suggestions presented in this article do not represent the official views of the NLRB, its General Counsel, or the author.

1 See Table I in the Appendix, p. 253 infra.

2 See Table II in the Appendix, p. 253 infra.

3 See Table III in the Appendix, p. 253 infra. 
I cannot even estimate the number of decisions I have read, or calculate my many discussions with General Counsels, NLRB members, other colleagues, knowledgeable scholars, and practitioners. I shall also refer to political theory and to behavioral and empirical studies of man as a voter.

One significant function of an election is to choose an agent to carry out the responsibilities of representation. For this to be accomplished, the process must lead to an undisputed result. The NLRB's election process best serves this function if:

1. competing parties are uncertain about the impact upon voters of campaign statements, speeches and literature, but are certain about the finality of results: meaningful and acceptable choice exists only so long as no party can control the voter's selection of his representative;

2. the voter is exposed to, and reacts to, a variety of concerns and pressures from all sides;

3. the NLRB does not oversee the propaganda and conduct of the parties but concentrates upon the results;

4. the goal of ideal conditions is eschewed, since it requires an intricate network of procedures and regulations negativing definitive results; and

5. every election unit has a regular and substantially uniform election process.

If one accepts the enumerated conditions as a useful framework, it should be possible to examine and analyze NLRB representation elections in order to determine whether the existing rules, standards, and procedures ${ }^{4}$ accomplish a desirable balance.

\section{Uncertainty-Certainty Paradox}

Representation elections, first used by the War Labor Board in World War I, and incorporated in the Railway Labor Act and

4 Throughout this article, "rules," "standards," "procedures," and similar expressions are used to refer to the NLRB's regulation of employer and union campaign tactics that do not constitute unfair labor practices. Where the Board finds that substantial employer unfair labor practices occurred before an election lost by the union, the Board will require the employer to bargain with the union if it can demonstrate that a majority of workers signed authorization cards before the election. Irving Air Chute Co., 149 N.L.R.B. 627 (1964); Bernel Foam Prods. Co., 146 N.L.R.B. 1277 (1964). See generally Comment, Employer "Good Faith Doubt," 116 U. PA. L. Rev. 709 (1968).

545 U.S.C. $\$ \S 151-88$ (1964). 
Wagner Act, ${ }^{6}$ were accepted as the legitimate means for determining employee representation as part of a broader scheme to establish lawful collective bargaining. The election is not an end in itself, but a means for choosing or rejecting a union. To be meaningful, and to gain acceptance from workers, unions, employers, and the public, election results must be uncontrolled and uncontrollable. If the results can be predetermined, then elections are not a choice but a rubber-stamp approval of a choice made elsewhere. Elections are the critical process in a democratic system. ${ }^{7}$

Employers and unions should be uncertain about the particular impact of statements, speeches, literature, and conversations upon workers, but should be certain about the finality of election results. This is the paradox and strength of the democratic process: unsure means produce sure results. Elections are competitive, leading to a single winner. However intense the competitive struggle, definitive results are the functional requisite. Having participated in deliberately contrived and uncontrolled competition, losers must accept the results; otherwise, elections fail to fulfill their function. Chaos would disrupt our political system if twenty per cent of the losing candidates challenged the results of their elections, as do twenty per cent of the losers in NLRB elections.

\section{WorkER-VOter AND CITIZEN-Voter}

The worker-voter is the same human being as the citizen-voter. In NLRB elections, he is subject to the same kinds of internal and external influences as in political elections. He is influenced by status, role, residence, religion, race, national origin, and reference groups; by relatives, fellow workers, and superiors; and by numerous incalculable and unperceived emotional and psychological pressures.

Those persons who support standards governing propaganda in NLRB elections argue that since the employer has an inherent economic advantage over the electorate, his propaganda will always be considered in light of an assumption by employees that economic reprisals will follow a pro-union vote. One weakness of this argument is that it does not differentiate the various possible balances of power between employers and unions; but its principal underlying fallacy is

6 National Labor Relations Act, ch. 352, $\$ 9,49$ Stat. 453. At present, the right of an employer, union, or employee to petition the NLRB for a representation election is guaranteed by National Labor Relations Act [hereinafter cited as NLRA] $\$ 9$ (c), 29 U.S.C. \&159(c) (1964).

7 Joseph A. Schumpeter defined the "democratic method" as "that institutional arrangement for arriving at political decisions in which individuals acquire the power to decide by means of competitive struggle for the people's vote." J. SCHUMPETER, Capitalism, Soctalism, and Demiocracy 269 (3d ed. 1962). 
the assumption that the proximate cause of the worker's choice is the employer-employee relationship rather than some other factor or factors. We should be cautious about conceiving NLRB elections as essentially different from political elections, because a comparison of the evidence from political elections ${ }^{8}$ and the data from a carefully designed empirical study of voters in an NLRB election casts doubt upon this assumption, and because several thoughtful scholars do not see worker-voters as a unique electorate.

Professor Irving Brotslaw studied workers' attitudes in one NLRB election where the Board had sustained the union's objections. He concluded:

A majority of the respondents seemed to feel that the tactics alleged to have been employed by the company as part of its effort to defeat the union did not create a coercive atmosphere which rendered impossible the holding of a fair election, even though the union's charges to this effect [i.e., objections] were later upheld by the NLRB. This raises the question of whether employees subjected to pressures and counter-pressures exerted by a union and/or company during a representation election fully perceive the effect upon voting behavior attributable to the campaigns conducted by the respective parties. $^{9}$

Undoubtedly, the decision to vote for or against union representation is the product of numerous factors, which are not easily isolated for analytical purposes. ${ }^{10}$

Perhaps Professor Brotslaw's most significant finding concerns relationships among the variables influencing a voter's choice:

[T] here did seem to be a positive association between the union status of the respondents' father and/or close friends and voting behavior. Similarly, those respondents with previous work experience (particularly those who had previously worked in manufacturing establishments) and those who had been union members on previous jobs, were more inclined to vote in favor of union representation. ${ }^{11}$

8 See, e.g., Anrerican Voring Behavior (E. Burdick \& J. Brodbeck eds. 1959); B. Berelson, P. Lazarsfeld \& W. McPhee, Voting 277-323 (1954); A. Campbeix, P. Converse, W. Miller \& D. Stokes, The American Voter (1964); S. Kelly, Political Campaigning (1960); R. Lane, Polrtical life 46-52 (1959); P. Lazarsfeld, B. Berelson, \& H. Gaudet, The People's Choice (2d ed. 1948); S. LIPset, Political MaN (1963).

9 Brotslaw, Attitude of Retail Workers Toward Union Organization, 18 Lab. L.J. 149,170 (1967) (emphasis added). To my knowledge this is the only empirical study that systematically explores and analyzes the factors bearing upon workers' choices in an NLRB election.

$10 \mathrm{Id}$. at 156.

11 Id. at 169 . 
Professor Derek Bok, in his masterful and comprehensive analysis of campaign tactics in NLRB elections, appears to support the view that worker-voters, like citizen-voters, react unpredictably to campaign pressures. The effects of

[t]hreats and other appeals to fear and emotion [as well as] the subtler aspects of a campaign-restrictions on distribution, inaccurate statements, interrogation by the employer, and the like- . . are . . difficult to guage. ${ }^{12}$

Whether or not NLRB and political elections are analogous, as I believe they are, it is indisputable that the influences of campaign tactics upon both the worker-voter and the citizen-voter are unknown, if not unknowable.

\section{Political and NLRB Elections}

Generally, the Board differentiates between NLRB and political elections, and conceives its role as insuring uninhibited choice by employees.

A Board election is not identical with a political election. [T] he Board not only conducts elections, but it also oversees the propaganda activities of the participants in the election to insure that the voters have the opportunity of exercising a reasoned, untrammeled choice for or against labor organizations seeking representation rights. ${ }^{13}$

Because the Board treats worker-voters as a special kind of electorate requiring insulation from certain kinds of propaganda, the Board must subordinate the determinative results that are crucial in political elections in order to guarantee laboratory conditions.

Aside from the question whether NLRB and political elections are analogous, ${ }^{14}$ their similarities bear upon the necessity of definitive results. The following can be identified as common features.

1. Human beings, belonging to a diverse but integrated society and sharing similar experiences, vote in both.

2. The function of both elections is to select a representative; even though the voters in NLRB elections may reject a union, they thereby select the employer as their agent.

12 Bok, The Regulation of Campaign Tactics in Representation Elections Under the National Labor Relations Act, 78 HARv. L. REv. 38, 41 (1964) [hereinafter cited as Bok].

13 Sewell Mfg. Co., 138 N.L.R.B. 66, 69 (1962).

14 With reference to "considerations of propriety" in political elections and NLRB elections, Bok concludes, "It is hard to make out any general case for departing fundamentally from [our political] experience in administering the NLRA." Bok 56-57. 
3. Both types of election involve intense competition for the voters' support.

4. In both, there are a variety of appeals, distortions, pressures, inducements, and fears.

5. In both, voters seek to satisfy a variety of needs, wants, and interests.

6. In both, neither the competitive parties, nor the candidates, nor the voters know what is the proximate cause or reason for any specific choice.

7. In both, truly rational choices are probably never achieved.

8. In both, accepted results are one means for arriving at the stable, though temporary, consensus necessary for the operation of the political or collective bargaining system.

Despite the numerous significant common features of political and NLRB elections, the Board consistently departs from our experience in political elections. The Board not only oversees the campaign activities of all parties, but also seeks to establish ever higher standards to insure workers a sober, reasoned, informed, and untrammeled choice. According to the Board, what misleads and misinforms workers and what plays upon their feelings is neither fixed nor immutable, and must be evaluated in each challenged election. Note the contrast with our handling of electioneering in political campaigns, and the priority given to political election results.

Of no apparent significance to the Board are the following facts:

1. The number of objections has doubled in a decade.

2. The four unions using NLRB election services most frequently file a comparatively low percentage of objections.

3. A handful of unions are responsible for filing most objections.

4. There are no data showing any causal relationship between campaign propaganda and election results. ${ }^{15}$

15 Perhaps I should note one exception. In his statement to the Special Labor Subcommittee of the House Education and Labor Committee on August 7, 1967, William L. Kircher, Director of the Department of Organization of the AFL-CIO, reported the results of an NLRB election study conducted by his staff. Using a sample of 495 elections, the study shows that in the $94 \%$ where employers conducted antiunion campaigns, unions won $52 \%$, whereas in the $6 \%$ where there was no company opposition unions won 28 out of 29 , and tied the other. Kircher's conclusion from the data is that since it is "very natural for workers to unionize," employers must create an "essentially unnatural atmosphere" through propaganda and conduct to defeat unions. Apart from my reservations regarding the objectivity of research designed and conducted by AFL-CIO representatives, I don't believe that this study refutes the evidence adduced by Professor Brotslaw, the conclusions of Professor Bok, and my own experiences with objections. Unhappily, rigorous systematic studies of NLRB elections are lacking. 
It is not surprising, therefore, that Professor Bok questioned the validity of basing NLRB standards on the assumption that particular propaganda or conduct has a substantial or probable tendency to affect the worker's vote. Professor Benjamin Aaron has noted more critically that

the Board has indulged in some uncommonly silly and completely unverified assumptions that various forms of speech or conduct will or will not interfere with the employee's free choice of a bargaining agent. ${ }^{16}$

I submit that the similarities between NLRB and political elections are significant in assessing the functional role of conclusive results. Just as we do not try in political elections to determine what propaganda is pertinent and what is not, the NLRB should not attempt to establish standards governing electioneering. If NLRB elections are to serve their function, the parties should be uncertain about the consequences of their propaganda. They should have to use the broadest appeals, never sure of the worker's preference. Since the worker-voter and the citizen-voter are the same human being, the prospect of conditioning his NLRB choice is as unlikely as the probability of determining his political vote. But the Board, believing its duty is to insure a valid choice by workers, aims for ideal election conditions and thereby tends to subordinate the conclusiveness of results.

\section{The NLRB's Role as Overseer of Elections}

In its self-determined role as overseer, the Board seeks "to provide a laboratory in which an experiment may be conducted, under conditions as nearly ideal as possible, to determine the uninhibted desires of the employees." 17 The Board is concerned with rationality, fairness, and equality, not with results. But can any elections be conducted under antiseptic conditions? Can they be germ-free? Or must campaigns be filled with swirling eddies of propaganda, disingenuous threats and promises, feelings, ideologies and rhetorical bombast? Isn't it fatuous to expect employers and unions to rely solely upon sober and reasonable arguments and upon facts accurately stated? Can the Board establish workable standards for electioneering in diverse geographic and industrial settings without risking more and more disputed results? I submit that the Board has set itself an unattainable goal in assuming the role of overseer.

16 Aaron, Labor Relations Law, in Challenges to Collective Bargaining 113, 128 (L. Ulman ed. 1967).

17 General Shoe Corp., 77 N.L.R.B. 124, 127 (1948). 
In the Board's view, the true purpose of its elections is not necessarily to reach undisputed results, but rather to create an atmosphere in which the "surrounding conditions enable employees to register a free and untrammeled choice for or against a bargaining representative." 18 Election results are unacceptable to the Board, whatever the margin of victory, if propaganda or conduct so tainted the atmosphere that there could be no uninhibited, sober, and informed vote to reveal the workers' true choice. By making the surrounding conditions the touchstone for validating or invalidating results, the Board has made a choice between impermissible electioneering and finality.

I have deliberately polarized the issue, even though the Board has attempted to discriminate between various types of electioneering. ${ }^{19}$ Apparently the Board considers certainty less important than ideal campaign conditions, for the Board seems unaffected by the rising number of objections that result in part from the largely unsuccessful effort to establish fair election standards. Even without regard for the validity of theories about the effect of electioneering, the fact of increased objections is one worthy of attention.

I suspect that the Board has based its election controls on a self-fulfilling prophecy about employees. ${ }^{20}$ The Board, employers, and unions assume that workers are generally like amoebas-unthinking, unfeeling, passive, and reactive-easily swayed, unable to evaluate, and susceptible to propaganda, promises, and blandishments. ${ }^{21}$ The Board, employers, and unions seem to reject the view that workers are generally reasonable, capable of acting in their own interests, and open to change. ${ }^{22}$ Hence, when workers reject a union, agents attribute the loss to threats, promises, and distortions by the employer, which manipulated the votes of the passive and easily swayed workers. Further, the union agents assert that because of the employer's superior economic power, both his message and his

18 Id. at 126.

19 See, e.g., Hollywood Ceramics Co., 140 N.L.R.B. 221 (1962); Gummed Prods. Co., 112 N.L.R.B. 1092 (1955).

20 Our view of the future, by affecting our present anxieties, thoughts and action affects the future itself, since it is determined in part by what we believe it is going to be. A self-fulfilling prophecy is one that, although false at the time it is pronounced, influences behavior to such an extent that the prophecy comes to pass. The prophecy fulfills itself by virtue of its pronouncement. Both unions and employers believe that workers would support or reject representation, respectively, if the other party's false, threatening and deceptive propaganda was refuted. Acting on this belief, each utilizes propanganda on the basis of a false prophecy, and believes that whatever the results, they came about by virtue of one party's electioneering behavior. See R. MERTon, Social Theory AND Social Structure 421-26 (rev. ed. 1957).

21 "[L] egal rules will never succeed in making voters more rational than they are willing and able to become." Bok 48.

22 "Personality is less a finished product than a transitive process. While it has some stable features, it is at the same time continually undergoing change." G. ALLPORT, BECOMING 19 (1960). 
means of dissemination prevented workers from making a free, true, and natural choice, that is, voting for the union. This argument that the employees would have voted for the union but for the employer's economic power is based on the questionable premise that "[p]ower can persuade and substantial power can persuade substantially." 23

Yet no one has explained the impact of electioneering upon whatever minority of voters supported the union. If the Board sets aside an election because the workers rejected the union as a result of impermissible employer propaganda, the necessary implication is that some unknown portion of the majority would have voted for the union but for the unlawful electioneering. On the other hand, the minority voting for the union were not sufficiently influenced by the employer's propaganda to vote against the union. ${ }^{24}$ By examining the statistics, we cannot discover the identity and characteristics of the workers who were or were not affected. Hence, the Board can only look to the propaganda to deduce in some mysterious manner that the free choice of a critical number of unknown workers was influenced. Should the self-fulfilled prophecy that employees can be prejudicially influenced be transmuted into a controlling rule overriding election results?

Employers, like unions, are captive to the self-fulfilling prophecy. It is unthinkable to employers that rational, free, and self-directed workers would ever pick a collective agent in place of individual bargaining. Hence, employers believe that but for union propaganda their employees would naturally reject unions. To employers, a union majority is solely the result of union threats, misrepresentations, exaggerations, or downright lies cleverly conveyed to unknowing, unthinking and undiscriminating workers. The prophecy is fulfilled whenever workers pick a union.

Piously asserting that the pre-election atmosphere must be inpolluted and uninhibiting, employers are increasingly filing objections.

23 Thomas Prods. Co., 167 N.L.R.B. No. 106, 1968-1 CCH NLRB Dec. \21-810, at 28,582 (Oct. 12, 1967). This twist of Lord Acton's famous maxim ignores considerable scholarship that suggests the concept of power be considered in terms of countervailing power, net power, and power relationships. Power is not "[g]old bullionphysically piled on someone's desk, infinitely fungible unit for unit, and indifferently expendable to achieve any result." Manning, Corporate Pozver and Individual Freedom, $55 \mathrm{Nw}$. U. I. Rev. 38, 44 (1960). "Power in America seems . . . situational and mercurial; it resists attempts to locate it in the way a molecule, under the Heisenberg principle, resists attempts simultaneously to locate it and time its velocity." D. Riesman, N. Glazer \& R. Denney, The Lonely Crowd 257 (1955).

24 "Men with power to affect the economic life-chances of a large group may exert little interpersonal influence in other spheres: the power to withhold jobs from people may not result in directly influencing their political or associational or religious behavior." Merton, Patterns of Influence: A Study of Interpersonal Influence and of Communications Behavior in a Local Community in Communications Research: 1948-1949, at 217 (P. Lazarsfeld \& F. Stanton eds. 1949). 
But by refusing to accept an adverse vote, employers, like unions, are showing a lack of concern for finality. This is hardly fair. Both employers and unions are obviously concerned with final election results, namely, those in their own interest. Only the Board, not employers or unions, is really interested in overseeing propaganda. Yet all appear to rely upon the self-fulfilling prophecy of undue influence.

There is one significant difference between employers and unions regarding the outcome of balloting. Unlike unions, employers can postpone the certainty of elections not only by filing objections but also by resisting bargaining. Further, their successful overall record in the courts probably encourages employers to disobey bargaining orders in situations where their objections have been overruled. ${ }^{25}$

More specifically, there is a variety of possible reasons why employers are filing more objections. Perhaps they have learned the advantages of disputing results, particularly when the union's margin of victory is small. ${ }^{26}$ The following list of possible causes, though not exhaustive, should help to explain the increase in employer objections.

1. Where the union's majority is thin, the time required to process objections may erode union support.

2. When employer objections are filed, the union must divert its resources to defend the legality of the election instead of using them to build its organization.

3. Objections delay bargaining and to that extent save the employer bargaining expenses and the cost of possible increased employee benefits.

4. An enlarged complex of rules governing election propaganda provides more opportunities for employer objections, and more knowledgeable employer attorneys, many of whom are former NLRB employees, provide the capability to take advantage of objection opportunities.

5. After objections are filed, the probability of success increases as the employer moves from the investigations to the hearing, to the Board, and eventually to the courts.

6. Even if the employer's objections are overruled and he exhausts all avenues of review, he has a chance of inducing the union

${ }^{25}$ See, e.g., NLRB v. Bata Shoe Co., 377 F.2d 821 (4th Cir. 1967), cert. denied, 389 U.S. 917 (1967), denying enf. to 157 N.L.R.B. 1 (1966).

26 Although the Board almost never adverts to the margin of victory as a factor in deciding objections, I suspect that it is a latent element; certainly, the Board, courts, and regional directors are aware of the results of the election. 
to withdraw because it has lost the employees' support, and at least one chance in three of changing the initial results. ${ }^{2 \pi}$

7. By filing objections the employer acquires a legitimate forum for dramatically exposing the union's alleged misconduct, misrepresentation, and chicanery.

Every NLRB and court decision provides new grounds for filing employer objections. Whether the union's electioneering is upheld or disallowed, employers can ingeniously exploit the facts and arguments in the opinion. If the enumerated reasons for employer objections are valid, then the Board's concentration upon laboratory conditions and relative unconcern about conclusive results will surely produce more and more objections.

The point here is that the Board's self-conceived role as overseer in NLRB elections needs critical reexamination. Elections cannot be conducted under ideal conditions. Whatever the workers' true choice may be as an abstract proposition, the human characteristics of the voters and the competitive union-employer struggle cast serious doubt on the likelihood of establishing workable election standards. Moreover, the underlying support for devising usable criteria stems from unthinking adherence to self-fulfilling prophecies, which probably in part explains the rising number of objections. Finally, the Board's role as overseer also seems to contribute to the increased number of employer objections, a consequence clearly dysfunctional to the election process. What is called for is a shift from concern with electioneering to an emphasis on certainty of results.

\section{The Costs of Inconclusive Elections}

The direct and indirect costs of inconclusive elections to the Board and the parties must be measured against the savings of conclusive elections. Although my colleagues may not share many of the views expressed in this paper, they are virtually united in their opposition to expending funds for handling objections. Maybe our administrative (bureaucratic?) skirts are showing, but somehow we feel that once the tally of ballots is handed to the parties the election should be over.

NLRB costs are incurred for investigations, hearings, transcripts, correspondence and reports, among other things. These represent an investment that could otherwise be devoted to activities

27 This probability is inferred and extrapolated from two studies of rerun elections: Drotning, NLRB Remedies for Election Misconduct: An Analysis of Election Outcomes and Their Determinants, 40 U. CHI. J. Bus. 137 (1967) ; Pollitt, NLRB Re-Run Elections: A Study, 41 N.C. L. Rev. 209 (1963). In the Pollitt study, employer and union objections were mixed, whereas in the Drotning study, only cases involving union-filed objections were considered. 
more likely to improve the quality and efficiency of NLRB output. Some may argue that if the aim of achieving fair elections is worthwhile, then any expenditure to secure this aim is warranted. But since rational administrators must always balance finite resources against infinite demands for allocation, and since every citizen wants the Board to spend its money wisely and effectively, this contention hardly meets the issue.

The NLRB has indicated that the gains achieved through its role as overseer outweigh the costs. ${ }^{28}$ Apparently, the party disputing the results prefers his costs to an adverse result. Yet I wonder whether unions or employers calculate the costs in terms of workers' productivity, diversion of managerial and union energies, and legal and administrative services. All parties, including the NLRB, should heed Professor Bok's perceptive comments:

The inconvenience and administrative costs that result from a complex regulatory system are factors to be considered in deciding whether rules of more doubtful significance should be imposed. Moreover, in view of the problems arising from the heavy workload of the Board, administrative costs should have a bearing on the form in which rules are cast and, more important still, on the creation of effective sanctions for these rules. ${ }^{29}$

I do not suggest that costs must be the decisive consideration, but I do suggest that they must be weighed in evaluating NLRB rules governing elections. Because "a complex regulatory system" raises costs, each new NLRB election rule must meet the test of prudent allocation of resources. The NLRB's preoccupation with laboratory conditions produces more disputed elections and increased costs. ${ }^{30} \mathrm{~A}$ shift from concern about campaign tactics to concern about results would remove many grounds for invalidating elections; a reduction in the number of objections would lower expenditures for the Board, unions, and employers. The Board could shift its energies to devising procedural rules that would provide employers and unions equal opportunities to persuade workers. There can be no fruitful appraisal of existing rules unless their costs are compared with the costs of an alternative regulatory system.

28 In a case involving both objections and unfair labor practices the Board said: ". . considerations of economy, in our view, must be subordinated to the overriding policies of the Act." Bernel Foam Prods. Co., 146 N.L.R.B. 1277, 1281 (1964).

29 Bok 66.

30 The increase in costs can be illustrated by a recent case, in which four years of investigation and litigation were required to determine the impact on laboratory conditions of a rumor that the employer would fire all Negro employees if the union lost the election. Staub Cleaners, Inc., 148 N.I.R.B. 278 (1964), remanded, 357 F.2d 1 (2d Cir. 1966), aff'd, 171 N.L.R.B. No. 40, 1968-1 CCH NLRB Dec. $\llbracket 22,448$ (May 13, 1968). 


\section{Standard Election Rules}

The establishment of definitive election results would help the Board achieve standardized election rules. As a national agency, the Board must formulate rules of decision to govern elections throughout the country. Few would contend that propaganda directed at workers in a highly-unionized community with some degree of sophistication in labor matters and good job opportunities has the same impact as propaganda in an isolated, antiunion community with high unemployment. Since NLRB standards for judging propaganda must be applied nondiscriminatorily across the country, they cannot vary to suit the sharply contrasting communities of this country. In attempting to meet its federal responsibilities, the Board has vacillated between the following approaches: (1) it has tried to generalize election rules to the degree necessary to fit all kinds of propaganda; and (2) it has evolved complex rules to cover every unique situation. ${ }^{31}$

An examination of NLRB decisions documents the above shifts, and suggests that continued subordination of conclusive results is likely to produce a more intricate network of rules. Analysis of one well settled NLRB rule should illustrate and sharpen the issue. The Board holds that an employer's threat to shut the plant if the union wins is sufficient grounds on which to set aside the election should the union lose. Sophisticated employers are counseled to avoid. such crass threats. Instead, workers are told about the shutdown of a nearby unionized plant. The causal connection between unionization and plant shutdown is not articulated, but there can be no doubt that the workers get the message. No one could catalogue the number of variations on this theme. Depending on the employer's language, the Board will either sustain or overrule objections. On first impression, it might appear that the Board has formulated a uniform national standard. But in application, the standard has many variations.

In fairness to employers, I should use an illustration involving unions. Generally, union agents may not threaten or intimidate workers directly during the pre-election period. But threats made by rankand-file employees-unsponsored, unheard, and unratified by the union - can be circulated without necessarily invalidating the election results. Pro-union employees can and do tell workers that if the union wins and they didn't support it, the union will get them fired. ${ }^{32}$ The voters get the message. Are such rank-and-filers the proper medium?

NLRB decisions and administrative experience make it clear that employers and unions painstakingly peruse each decision and then

31 Dubin, Prospects of Industrial Conflict-A Prediction, in Industrual ConFLICT 529 (A. Kornhauser, R. Dubin \& A. Ross eds. 1954).

32 Some unions also rely upon planted rumors for support. Bok 87 n.132. 
modify their electioneering strategies with the dual aim of exploiting favorable propaganda and avoiding NLRB invalidation of desired results. It appears that the parties are playing a costly charade, principally because the Board affords them standards against which to measure campaign tactics.

It is well to remember that this type of maneuvering is inherent in elections, and the Board recognizes this. But the Board is overburdened with establishing and implementing some form of ideal conditions. Since it cannot consistently maintain national uniformity, the Board is pushed ineluctably toward myriad rules covering every idiosyncratic situation. $^{33}$ A complex regulatory system should be avoided. Conclusive results are crucial to the election process, and the NLRB is more likely to achieve workable national standards if it concentrates upon results rather than electioneering.

\section{The One-Year Election Bar}

Up to this point I have discussed and analyzed the NLRB's treatment of objections to elections in the framework of the election process. The background for the discussion has been the marked increase in objections, and I have indicated that these would be reduced if the Board focused on making election results conclusive. To round out our consideration, I will identify and review a statutory provision that is probably a significant cause for increased union objections. I believe that unions would file fewer objections if the one-year election bar of section 9 (c) (3) ${ }^{34}$ were deleted from the statute.

In substance, section 9(c)(3) permits only one valid election each year in any bargaining unit or subdivision. The object of this provision is to prevent employers from being subjected to repeated elections with their attendant costs, harassments, and propaganda. Section 9 (c) (3) does not foreclose perpetual organizing, but it does

33 There is a longstanding debate between those favoring NLRB substantive rules and those supporting a case-by-case approach. In elections, the Board uses the latter approach for developing substantive guides, which are applied in subsequent cases. Whether the Board's exercise of its rule-making power would undesirably limit adaptation to new situations is not the question here. I only suggest that the Board's present course of developing decisional guides to achieve laboratory conditions produces many nonuniform rules. I consider this complex regulatory system an unwanted and unproductive consequence of the disregard for conclusiveness. Professor Peck has concluded that the ". . . NLRB's exclusive reliance upon an ad hoc approach . . . has produced grossly unsatisfactory results," Peck, Atrophied Rule-Making Pozvers of the National Labor Relations Board, 70 YALE L.J. 729, 761 (1961), and that "the Board's insistence on proceeding only by adjudication has deprived us of the clarification and certainty that might be obtained through rule-making." Peck, $A$ Critique of the National Labor Relations Board's Performance in Policy Formulation: Adjudication and Rule-Making, 117 U. PA. L. REv. 254, 270 (1968).

34 NLRA $\$ 9$ (c) (3), 29 U.S.C. \$159(c) (3) (1964). 
preclude certification within one year of a valid election that the union loses.

In some situations the union cannot walk away despite adverse election results. It may have to continue activities because the employer is competing with unionized firms. Or it may want to maintain a cohesive nucleus to protect its employee supporters from employer reprisals. Whatever the reasons, some union organizations persist even after unfavorable election results.

If unions were allowed by statute to seek a second election within one year, the number of their objections would diminish. Presently, some unions exploit objections to keep their organizations viable, as well as to invalidate the lost election and obtain a rerun. Prior to the Taft-Hartley Act, the NLRB conducted new elections irrespective of the elapsed time on the condition that the union furnish a number of fresh authorization cards larger than the number of votes it had received. Although few reruns were conducted under the Wagner Act within one year of an unsuccessful election, unions could at least try again, provided they met the necessary conditions. I suspect that this opportunity tended to inhibit some unions from filing objections.

I think it fair to say that section $9(\mathrm{c})(3)$ and section 8 (b) (7) (C) ${ }^{35}$ tend to restrict unions from obtaining certifications through elections. An unwanted and generally unnoticed consequence is more union objections. One way to reduce such objections would be to remove the one-year election bar and return to the practice followed under the Wagner Act. Since the earlier arrangement worked and yielded fewer objections, the one-year election bar deserves excision. Allowing reruns within a year under certain conditions and providing for conclusive election results would benefit the public, unions, and employers, because diminution of objections facilitates the functioning of the election process.

\section{Determinative Challenges}

Although the increase in determinative challenges to ballots from 4.4 per cent to 6.6 per cent is not of the same magnitude as the increase in objections, determinative challenges also postpone definitive results. Thus, if the election process is to meet its functional requi-

35 NLRA \& 8(b) (7) (C), 29 U.S.C. \$158(b) (7) (C) (1964). Section 8(b) (7) (C) provides that primary union picketing for an organizational or recognitional object may be enjoined unless a petition is filed within a reasonable period of time not to exceed 30 days from the beginning of such picketing. One popular employer stratagem is to file a petition in the hope that the union will lose the election and thus be foreclosed for one year from obtaining certification. Organizational and recognitional picketing is generally confined to market-oriented unions. But section 8(b) (7) (C) may provoke such unions to file objections, and in fact, 3 out of the 4 unions filing most objections fall into this category. Samoff, Recognition and Organizational Picketing-A Wider Angle of Vision, 14 LAB. L.J. 891 (1963). 
sites, suitable means must be found for reducing, if not eliminating, such challenges. With the dual aim of achieving certainty in elections and satisfying due process, I recommend a procedure that should substantially reduce determinative challenges.

Under current practice, the Board agent tries to resolve challenges to ballots before the unchallenged ballots are tallied. If authorized representatives are present, if they are prepared to resolve challenges, and if the relevant information is available, the agent's task is easy. Agents are encouraged to resolve challenges before the votes are counted, and many challenges are disposed of by agreement of the parties at that time. However, for various reasons and in diverse circumstances the challenges are unresolved.

How should we handle challenges where the parties will not agree to resolve them before the votes are counted? Analogizing from political elections, I propose that the Board authorize NLRB agents to decide challenges despite any lack of agreement. It is crucial to dispose of challenges before the votes are counted. Once the unchallenged ballots are tabulated and unopened challenges become determinative, the parties harden their positions. They estimate the probable choice in each challenged ballot and devise strategies intended to achieve favorable disposition according to their predictions. Moreover, workers who cast the challenged votes may be harassed and pressured by unions or employers, and must become involved in the NLRB investigation. If challenged ballots are eventually opened and counted, the choices of the particular voters are no longer secret.

Under my proposal, NLRB agents would determine the validity of the challenged ballots before the count. In these situations, early availability of the list of eligibile voters required by the Excelsior rule $^{36}$ would obviously be valuable. Lacking agreement of the parties, agents would consider the facts and contentions on each side, and determine which challenged votes to count and which to leave uncounted. Ballots found valid would be opened and commingled with the unchallenged votes, and all of them would be tallied. If the challenged votes remaining unopened were still determinative, the usual investigation and report would be made. If any party were dissatisfied with the agent's ruling on challenges, it could file objections. But the proposal would not add to the number of objections because agents would generally make sensible rulings that most parties would accept. If the number of determinative challenges were reduced, results would become more conclusive.

30 Under this rule, which is observed by most employers, unions must be given lists of the names and addresses of eligible voters at least 10 days before an election. Excelsior Underwear, Inc., 156 N.L.R.B. 1236 (1966). 
With advance knowledge of the agent's authority to resolve challenged ballots, the parties would come to the ballot count prepared to review questions of eligibility. Entrusted with this authority and encouraged to exercise it, NLRB agents would be better prepared to handle disputed ballots. It is rare in political elections for candidates or parties to dispute a judge's disposition of questioned ballots. I anticipate similar consequences in NLRB elections under my proposal. Most important, results would be made more conclusive.

\section{Implications and Emerging Themes}

The major point of this paper is simple. As shown in the Appendix, during the steady increase in NLRB elections since 1958, the percentage of objections has more than doubled. Whatever the causes for this substantial increase, it is certain that inconclusive elections are dysfunctional to a system for resolving representation questions as the foundation for collective bargaining. The magnitude of unsettled and unstabilizing elections (19.4 per cent) has reached an alarming level.

These statistics are not disquieting to those who believe that insulating workers from improper influences is the highest goal of the system. When one is faced with obvious appeals to racism, thinly veiled threats, a movie like And Women Must Weep cleverly contrived "to paint a fearful picture of what could happen to employees if they voted . . . for union representation," ${ }^{37}$ or gross exaggerations of union benefits at other plants, a sense of outrage impels one toward a finding of illegality. I have wrestled frequently with such situations and know the difficulties of deciding in a particular case whether the campaign tactics did or did not interfere with the employees' free choice.

But the statistics cannot be lightly brushed aside. Rules intended to enforce higher election standards are unable to create laboratory conditions by eliminating objectionable influences. Such rules are irrelevant to the election process and detract from the finality of election results. Moreover, election rules require "various assumptions of doubtful validity," and "assertions about the effects of campaign tactics that . . . are controversial since election behavior is too ambiguous to embrace [the] generalizations" 38 explicit in such rules.

Those who believe that the highest goal of elections is to register the workers' true choice endorse the present ad hoc guidelines intended to provide laboratory conditions, and believe that there is a reason-

37 Plochman \& Harrison-Cherry Lane Foods, Inc., 140 N.L.R.B. 130, 132 (1962).

38 Bok 45. 
able balance between permissible and impermissible campaign tactics. Presumably, they do not share Professor Aaron's view that the

Board's commendable desire to preserve the uncorruptability of the election process has led it to pursue, indefatigably and hopelessly, the goal first enunciated in General Shoe. . . . ${ }^{32}$

or the judgment of Professor Bok that

[t] he conclusion that emerges ... is simply that [flagrant employer intimidation] will be far less frequent than one might believe if one were to assume that employees are normally willing and able to reach rational conclusions in the general run of elections. ${ }^{40}$

It appears to me that if the Board continues along the same road there are bound to be more and more disputed elections. The Board's capacity for finding propaganda and conduct sufficient to upset elections will be matched by the parties' ingenuity in finding new grounds for filing objections. At some level of objections, elections will cease to fulfill their functions. I believe the warning signals are clear, and there is need for change. ${ }^{41}$

After more than three decades of overseeing campaign tactics, the Board's attempts to remove various influences that may impinge on voters do not seem effective. Indeed, Professor Aaron characterizes this task as hopeless. ${ }^{42}$ Professor Bok, in an article relying in part upon materials from political science and social psychology, which must be read to understand the dimensions of this subject, concludes:

Rules which purport to put parties on a more equal footing or to permit more rational decisions by the voters are likely to have a more speculative value than one might suppose on first impression. The decision whether to suppont a union is too often inescapably nonrational, the effects of campaign tactics on the employees too problematical, and the positions of the parties too difficult to compare to permit the administrator to intervene with any real confidence of furthering his objectives except in a limited range of situations. ${ }^{43}$

Professor Bok's judgment is supported by any fair analysis of the data, and is reinforced by the form and function of the election process. Since elections are a competitive struggle for the employees' votes, the parties should be uncertain about the effect of campaign

39 Aaron, stpra note 13 , at 128 (emphasis added).

40 Bok 53.

41 The first step in reassessing election controls should be to expand our limited empirical knowledge of relationships among factors in the election process.

12 See text at note 35 supra.

13 Bok 65 . 
tactics upon the voters' preference. At the same time, the process must end with undisputed results if the chosen representative is to play its legitimate role. Since the worker-voter and citizen-voter are the same human being, and since NLRB and political elections are functionally analogous, the voter in NLRB elections should be treated as capable of making a reasonable and self-interested choice.

If this article accurately portrays the election process, then the Board cannot effectively fulfill its role as overseer. Campaign tactics are unlikely ever to satisfy the requirement of laboratory conditions. Not only has the Board been ineffective in enforcing higher standards, in view of the increase in objections, but higher standards have contributed to rising costs. In attempting to formulate and implement uniform national standards, the Board has shifted from generality to myriad particular rules. But whether the standards are general or particular, the objections increase, at least partly as a result of the one-year election bar and the present procedure for handling challenges.

There are those who believe that only antiunion campaign tactics by employers are responsible for the substantial rejection of unions. But the unions may have had a higher percentage of victories prior to 1958 because the Board had fewer rules governing elections, fewer objections were filed, and the employers' antiunion electioneering was less sophisticated. The decline in union successes may be a result of increased opposition to unions by either employers or workers. And whatever the explanation, more NLRB rules governing elections have not reversed the trend.

One significant aspect of NLRB elections is that ninety per cent or more of the eligible voters consistently vote. Workers with such strong interest in election results are more likely to know the issues and less likely to be susceptible to propaganda than apathetic voters. Unlike political parties, which are interested only in getting their supporters to the polls, both unions and employers strive for maximum turnout in the belief that the result should be legitimized by the largest number of voters. Direct involvement, familiarity with the issues, appraisal of the propaganda, and maximum turnout could be the system's corrective for electioneering, exaggerations, and misrepresentations.

Serious questions have been raised about the Board's regulations controlling elections. Three contrasting approaches may be identified. First, the purists want the Board to invalidate even more elections and to evolve sanctions to deter parties from unlawful electioneering. Second, the balancers agree generally with the Board's efforts to dif- 
ferentiate tolerable and intolerable campaign tactics. Third, the equalitarians doubt whether the Board can promote a more rational choice or maintain minimum standards of propriety in elections. The equalitarians concentrate upon providing equal opportunities for all parties to persuade the employees, and upon establishing the finality of results. Obviously, I support the third approach.

The purists respond to more objections with more regulations governing elections. As more rerun elections are held, more and tougher sanctions are evolved. At some point, presumably, the parties will see the light and cease their disallowed electioneering so that workers can express their true choice. The assumption may be that at this point objections will vanish.

The approach of the purists reflects an unwarranted confidence in the capacity of law. The approach is also based on dubious assumptions, faulty reasoning, and conclusions not only unproved but invalid. It is well to remember that elections are held for the employees, not the parties. Because employees are not naturally for or against unions, and because unions and employers usually are, only the finality of the majority choice can cut off the contentions of the parties and make elections useful in our representation system. Given these features, the purists' position is neither tenable nor feasible.

With regard to the second approach, the conclusions of Professors Aaron, Bok, and Brotslaw, the studies of voting behavior by political scientists and social psychologists, and administrative experience in handling elections cast serious doubts on the NLRB's capacity to develop a balanced, enforceable set of regulations, and implement them without unreasonable expenditure of time and money. The stark fact of more and more inconclusive elections remains. However appealing the approach of the balancers, the various interests cannot be accommodated under a regulating scheme if finality of results is crucial. It is not sound public policy to attempt to control the uncontrollable. ${ }^{44}$

\section{ACCESS to Voters}

Over the decades, the Board has established rules governing access to voters. Although Professor Bok finds many to be "of debatable importance." 45 I believe that rules affording parties equal

44 Commenting upon the Board's treatment of wage increases before elections, Professor Bok wrote, "By not eonsidering [the purpose of a rule and the efficacy of its sanction] administrators run the risk of maintaining a rule of speculative value which cannot be adequately enforced, thus encouraging cynicism toward the law that is already too prevalent in this field." Bok 116.

$45 \mathrm{Id}$. at 103. 
opportunities to persuade workers are the only sound alternative, since the Board can neither ensure rational choice nor maintain standards of electioneering conduot. Communications are the core of every campaign. There is a steady stream of leaflets, letters, speeches, conferences, and conversations seeking to affect the worker's choice. The voter probably obtains most of his information from partisan messages. Although we do not know whether the information is really influential, at least the parties think it is. Further, our democratic tradition and political experience support equal access to voters by the competing parties.

My difference with the Board is not over its rules guaranteeing all sides reasonable opportunity to convey their views to voters. Rather, I oppose its unwillingness to rely on equal access as the basis for rejecting objections to the content of communications. I suggest concentration upon conclusive results as long as equal opportunities are available.

The Board has taken some steps in equalizing access. It now requires employers to furnish petitioning unions a list of the names and addresses of employees in the unit at least ten days before an election. ${ }^{46}$ With rare exceptions, employers furnish these lists. Failure to supply them in time is a basis for setting aside an election. Although the high level of compliance may stem from the Board's sanction, and from support by the courts, I have heard many employers and their attorneys endorse the Excelsior rule because they believe it fair and consistent with our democratic traditions.

In a few cases the Board has alluded to the lists to counter union objections to the content and form of employer communications. I suggest that such lists be considered prima facie evidence of equal access to voters and therefore grounds for overruling many objections to employer communications.

The Board has taken other steps to protect access to workers. When a petition is filed, the employer is requested to post an official, informational notice. It explains the representation procedure, identifies the rights of employees under the statute, and lists examples of employer and union conduct that may result in setting aside the election. Although there is no sanction for failure to post, and we have no data on how many employers post this notice, my impression is that most employers do post it.

The Board's official notice of election, which must be posted at least three days before the election by all employers, contains substan-

46 Excelsior Underwear, Inc., 156 N.L.R.B. 1236 (1966). Professor Bok proposed this requirement. Bok 99. 
tially the same information as the earlier notice, in addition to various ltems relevant to the balloting. Thus, voters are informed at least once before the election about their rights to freedom of choice and a secret ballot.

Although the notices are designed to safeguard the workers' informed and uncoerced choice, the Board has not relied upon posted notices as irrefutable grounds for overruling either union or employer objections. The availability of names and addresses, and the notices posted during the campaign period, assure that the voters are informed of their rights in NLRB balloting. These simple devices are easy to administer, and have been accepted by most employers. The Board is not required to oversee the form and content of campaign communications, and these procedural rules should enable the Board to focus upon conclusive results. Moreover, if unions and employers see that the Board has recognized the futility of trying to establish and enforce substantive rules governing propaganda, they will aid in the search for new procedural rules.

In some decisions the Board has relied upon opportunities for rebuttal or effective time to reply as the basis for overruling objections. ${ }^{47}$ Professor Bok has noted that

as the opportunity to reply is enhanced, the need for regulating the content of speech tends to diminish. . . . [A]n adequate opportunity to reply will go far to remove the need for expanding controls over the content of speech. . . . [T] here are persuasive reasons for concentrating on safeguarding these opportunities rather than imposing more intricate restrictions on the content of speeches and letters. ${ }^{48}$

It is unclear from the decisions whether effective time to reply invariably rebuts otherwise objectionable propaganda or is merely a "moreover" for a finding that electioneering was unobjectionable. The lack of clarity tends to give rise to vague and inconsistent rulings, which baffle the parties and the NLRB staff, and provoke further litigation. A rule regarding effective time to reply should be formulated

47 "Section $8(\mathrm{c})$ does not protect only those views, arguments or opinions that are correct, nor does it forbid them because they may be demonstrably incorrect. The remedy is for the union to answer them. . . NLRB v. TRW-Semi-Conductors, Inc., 385 F.2d 753, 760 (9th Cir. 1967), rev'g 159 N.L.R.B. 415 (1966). See also General Elec. Co. Specialty Control Dep't, 162 N.L.R.B. No. 91, 1967 CCH NLRB Dec. 121,035 (Jan. 16, 1967), enforced, 383 F.2d 152 (4th Cir. 1967); Elgin Butler Brick Co., 147 N.L.R.B. 1624, 1627 (1964); Ralston Purina Co., 147 N.L.R.B. 506, 509 (1964); American Greetings Corp., 146 N.L.R.B. 1440, 1444-45 n.4 (1964); The Holtite Mfg. Co., 146 N.L.R.B. 385 (1964); United States Rubber Co., 155 N.L.R.B. 1298 (1955), remanded, 373 F.2d 602 (5th Cir. 1967), rev'd, 169 N.L.R.B. No. 128, 1968-1 CCH' NLRB \22,161 (Feb. 19, 1968).

48 Bok 91-92. 
in simple terms to provide clear guidance and to facilitate inexpensive and effective enforcement. The three procedural standards discussed -adequate opportunity to reply, lists of voter names and addresses, and informational notices-are easy to understand and administer and should enable the Board to discontinue its futile attempts to establish laboratory conditions. ${ }^{49}$

If the NLRB, employers, and unions focused upon equal access to voters and finality of results, the existing substantive rules could be replaced with suitable procedural ones. After three decades of disuse, the Board could take advantage of its rulemaking power to promulgate clear procedural standards. ${ }^{50}$ In addition to the existing procedural devices, the following seem worthy of consideration: (1) joint employer-union debates in the plant and at union meetings; (2) radio and television question-and-answer sessions with a panel of correspondents; (3) posting of union campaign literature on plant bulletin boards; and (4) joint employer-union leaflets. Undoubtedly, the parties and the Board could conceive and accept a wide range of effective devices. Unlike the existing regulatory system, such procedures can achieve their aim because they are self-created, selfimposed, and self-enforced.

I believe that both unions and employers are sufficiently concerned about the rising number of objections to accept feasible alternatives, and to exchange the quest for unattainable ideal standards for equal access to voters. This conclusion is supported by an observation made by Professor Bok, before the Board required names and addresses and adopted the expanded election notice.

[A]lmost all of the organizers interviewed in the course of this study would trade the strict limitations on employer speech . . . in return for a more adequate opportunity to reply. ${ }^{51}$

Even without any reasonable expectation of providing a basis for overruling union objections based on employer propaganda, employers have almost unanimously furnished lists and posted notices. I believe that many employers would implement additional protective procedures if assured of fewer contested elections.

49 Another NLRB procedural rule rarely breached by the parties prohibits employers and unions from making election speeches on company time to assemblies of employees within 24 hours of an election. A violation of this rule provides a basis for setting aside the election upon the timely filing of objections. Peerless Plywood Co., 107 N.L.R.B. 427, 429 (1953).

50 Friendly, The Federal Administrative Agencies: The Need for Better Definition of Standards, 75 Harv. L. REv. 863 (1962).

51 Bok 91-92 (footnote omitted). 
Since our election system assumes that all citizens are capable of exercising good judgment in casting their ballots, ${ }^{52}$ since experience demonstrates that the NLRB's complex regulatory system is neither effective nor necessary, since statistics show more and more disputed elections, and since the costs of handling inconclusive elections are rising-the time has arrived for a searching reevaluation of current NLRB policies. A free election is more than a contest for the voter's preference; it is the process upon which representative collective bargaining depends. Neither the NLRB nor anyone else can decide what campaign information is pertinent and what is not. An NLRB election cannot be antiseptic. No one can say with any assurance what impels workers to vote one way or another. In every election campaign unforeseen events and unpredictable influences must be resolved by the voters in the privacy of the polling booth. The most that can be expected is that all parties will be able to present facts and arguments, and that the results will be final.

It is hard to discuss this subject without being misunderstood, and it is harder still to avoid sounding critical of the Board. I hope this article raises the right questions, presents a framework for examining alternatives to deal with the disquieting increase in inconclusive elections, and suggests ways of avoiding the unstabilizing effect of unsettled representation questions. Although views regarding the impact of propaganda and the desirability of achieving laboratory conditions are strongly held, I challenge those who believe that if the Board were to set aside more elections and evolve more stringent remedies, workers could decide without any improper pressures.

Finally, I propose that the NLRB deliberately refrain from deciding what are acceptable and unacceptable campaign tactics. As an active administrator, I know that it is easier to talk abstractly about possible changes than to resolve actual cases by a new method. It is difficult to theorize about campaign tactics when unions and employers are urging me to dismiss or sustain objections. Concentration upon procedural rules and conclusive results is obviously not a magical solution for the complex problem of election objections, particularly when they have to be applied by the Board and regional staffs in varied settings. Any solution carries with it gains and losses. We cannot anticipate all the consequences of new procedures. There will always

52 Confronted with a union bylaw affecting eligibility of members seeking union offices, the Supreme Court observed: “. . Congress' model of democratic elections [within unions] was political elections in this country . . . [I] n those elections the assumption is that voters will exercise common sense and judgment in casting their ballots. Local 6 made no showing that citizens assumed to make discriminating judgments in public elections cannot be relied on to make such judgments when voting as union members." Wirtz v. Hotel Employees Local 6, 391 U.S. 492, 504 (1968). 
be considerable partisan pressure. But I am convinced that changes are essential in view of the rising number of objections. My proposal -hearty and unrestricted electioneering, equal access to the voters, and conclusive results-is consistent with the representation scheme of the Act and the NLRB's experience in conducting elections. Whether or not it is implemented depends on our readiness to evaluate current methods and explore new ones. 


\section{APPENDIX}

\begin{tabular}{|c|c|c|c|c|c|}
\hline \multicolumn{6}{|c|}{ TabLe $I^{a}$} \\
\hline $\begin{array}{r}\text { Fiscal } \\
\text { Year }\end{array}$ & $\begin{array}{l}\text { No. of } \\
\text { Elections }\end{array}$ & $\begin{array}{c}\text { No. of Cases } \\
\text { Involving } \\
\text { Reports }\end{array}$ & $\begin{array}{c}\text { \%o of } \\
\text { Objections } \\
\text { in Electionse }\end{array}$ & $\begin{array}{c}\text { \% of } \\
\text { Determinative } \\
\text { Challenges }\end{array}$ & Total \\
\hline 1958 & 4,524 & 299 & 6.6 & 4.4 & 11.0 \\
\hline 1959 & 5,651 & 351 & 6.2 & 4.3 & 10.5 \\
\hline 1960 & 6,633 & 502 & 7.6 & 6.0 & 13.6 \\
\hline 1961 & 6,613 & 535 & 8.1 & 5.6 & 13.7 \\
\hline 1962 & 7,601 & 736 & 9.7 & 6.0 & 15.7 \\
\hline 1963 & 7,115 & $821^{\mathrm{d}}$ & 11.2 & 6.0 & 17.2 \\
\hline 1964 & 7,559 & 1,003 & 11.4 & 6.6 & 18.0 \\
\hline 1965 & 7,776 & 1,027 & 11.4 & 5.8 & 17.2 \\
\hline 1966 & 8,324 & 1,311 & 11.6 & 5.6 & 17.2 \\
\hline 1967 & 8,183 & 1,369 & 13.7 & 5.7 & 19.4 \\
\hline
\end{tabular}

TABLE II.

$\begin{array}{cccc}\begin{array}{c}\text { Fiscal } \\ \text { Year }\end{array} & \begin{array}{c}\text { \% of Employer } \\ \text { Objs. Filed }\end{array} & \begin{array}{c}\text { \% of Union } \\ \text { Objs. Filed }\end{array} & \text { Both } \\ 1960 & 20.0 & 80.0 & \\ 1963 & 23.6 & 76.4 & \\ 1964 & 24.9 & 73.9 & 1.2 \\ 1965 & 25.8 & 65.1 & 9.1 \\ 1966 & 27.9 & 64.0 & 8.1 \\ 1967 & 29.5 & 67.1 & 3.4\end{array}$

TABLE III.

$\begin{array}{ccc}\text { Fiscal } & \begin{array}{c}\text { No. of Reports on } \\ \text { Objections \& Challenges }\end{array} & \text { \% Increase } \\ 1965 & 1,156 & \\ 1966 & 1,244 & 7.6 \\ 1967 & 1,381 & 11.0\end{array}$

a The statistics are taken from NLRB Gen. Counser, Summary of Operatrons 1967 and 1968 (six months), and from 23-32 NLRB ANN. REP. (1958-67). The latter did not include detailed breakdowns until fiscal year 1964. 29 NLRB ANN. RkP. 183-85, tables 11 A-D (1964).

I am indebted to Martha Dunleavy, Chief of the Organization and Methods Branch of the NLRB, for explaining and reconciling the election statistics.

b There are discrepancies between the General Counsel's Simmaries and the Amulal Reports, since the former are based on written reports issued during the year for cases which may or may not have been closed, whereas the latter are based on cases closed during the year.

c These figures understate the percentage of objections and determinative challenges since they include only objections and challenges for which written reports were issued. Uncounted are cases where objections were withdrawn, where the parties agreed to a rerun election without the issuance of a report, or where objections were filed in rerun and runoff elections. Also uncounted are cases where one party agreed with the determinative challenge of the other and no report was issued. In fiscal year 1966,329 objections were withdrawn, and in fiscal year 1967, 342 were withdrawn.

d Note the drop in elections but increase in objections. Not only is there a progressive increase in the percentage of disputed elections, but also an increase in the absolute numbers of disputed elections since the higher percentage is on a higher base of total elections. 